\title{
Clinic Stay Indicator
}

National Cancer Institute

\section{Source}

National Cancer Institute. Clinic Stay Indicator. NCI Thesaurus. Code C124442.

An indication as to whether the subject was admitted to a healthcare clinic. 